Atmos. Chem. Phys., 13, 5873-5886, 2013

www.atmos-chem-phys.net/13/5873/2013/

doi:10.5194/acp-13-5873-2013

(c) Author(s) 2013. CC Attribution 3.0 License.

\title{
Modeling air pollution in Lebanon: evaluation at a suburban site in Beirut during summer
}

\author{
A. Waked ${ }^{1,2}$, C. Seigneur ${ }^{1}$, F. Couvidat ${ }^{1}$, Y. Kim ${ }^{1}$, K. Sartelet ${ }^{1}$, C. Afif ${ }^{2}$, A. Borbon ${ }^{3}$, P. Formenti ${ }^{3}$, and S. Sauvage \\ ${ }^{1}$ CEREA, Joint Laboratory École des Ponts ParisTech/EDF R\&D, Université Paris-Est, Champs-sur-Marne, France \\ ${ }^{2}$ Centre d'Analyses et de Recherche, Faculty of Sciences, Université Saint-Joseph, Beirut, Lebanon \\ ${ }^{3}$ LISA, CNRS UMR7583, Université Paris-Est Créteil and Université Paris Diderot, Institut Pierre-Simon Laplace, Créteil, \\ France \\ ${ }^{4}$ Ecole des Mines de Douai, Département Chimie Environnement, 59508 Douai, France
}

Correspondence to: A. Waked (wakeda@cerea.enpc.fr, antoine.waked@usj.edu.lb) and C. Seigneur(seigneur@cerea.enpc.fr)

Received: 21 August 2012 - Published in Atmos. Chem. Phys. Discuss.: 16 November 2012

Revised: 10 April 2013 - Accepted: 17 May 2013 - Published: 17 June 2013

\begin{abstract}
Beirut, the capital of Lebanon, which is located on the eastern shore of the Mediterranean basin, experiences high air pollution episodes. Annual average concentrations of coarse and fine particulate matter $\left(\mathrm{PM}_{2.5}\right)$ as well as nitrogen oxides $\left(\mathrm{NO}_{\mathrm{x}}\right)$ often exceed the World Health Organization (WHO) guidelines. Therefore, improving air quality in this region is essential. The Polyphemus/Polair3D modeling system is used here to investigate air pollution episodes in Beirut during 2 to 18 July 2011. The modeling domain covers two nested grids of 1 and $5 \mathrm{~km}$ horizontal resolution over greater Beirut and Lebanon, respectively. The anthropogenic emission inventory was developed earlier (Waked et al., 2012). The Weather and Research Forecasting (WRF) model is used to generate the meteorological fields and the Model of Emissions of Gases and Aerosols from Nature (MEGAN) is used for biogenic emissions. The results of the study are compared to measurements from a field campaign conducted in the suburb of Beirut during 2-18 July 2011. The model reproduces satisfactorily the concentrations of most gaseous pollutants, the total mass of $\mathrm{PM}_{2.5}$ as well as $\mathrm{PM}_{2.5}$ elemental carbon (EC), organic carbon (OC), and sulfate. Ozone concentrations are overestimated and it appears that this overestimation results mainly from the boundary conditions.
\end{abstract}

\section{Introduction}

The Middle East region is characterized by a diverse landscape including elevated terrain, semi-arid and desert areas, sea shores and vast plains. Covering fourteen Arab countries as well as Turkey and Iran, the region stretches from Egypt in the West to Iran in the East, Turkey in the North and the Arabian Peninsula in the South. Being an enclosed region, it experiences high air pollution episodes, elevated particulate matter (PM) concentrations and major acid deposition problems (Saliba et al., 2006 and references therein). Moreover, anthropogenic emissions are increasing rapidly over this region due to large industrialized areas, the absence of any efficient public transport system, dense traffic areas and high population densities (ESCWA, 2010; Lelieveld et al., 2009). In addition, steady winds originating from eastern Europe as well as intense solar radiation contribute to the formation of high levels of secondary pollutants and other reactive species (Lelieveld et al., 2002; Kouvarakis et al., 2000). To date, few studies have been conducted to investigate air pollution in this region. Lelieveld et al. $(2002,2009)$ and Smoydzin et al. (2012) investigated ozone $\left(\mathrm{O}_{3}\right)$ pollution over the Middle East region and the Arabian Peninsula. The results showed that in the Arabian Peninsula, high levels of $\mathrm{O}_{3}$ concentrations were observed especially in summer (Liu et al., 2009) due to the highly favorable weather conditions and high local air pollutant emissions (Lelieveld et al., 2009). In particular, nitrogen oxides $\left(\mathrm{NO}_{\mathrm{x}}\right)$ concentrations in this area are exceptionally high (Stavrakou et al., 2008). As a 
result, air pollution in this region needs to be investigated, monitored, and reduced. Lebanon, a small developing country in the Middle East region, located on the eastern shore of the Mediterranean Sea, experiences high pollution episodes due to local emissions because of a growing population, especially in urban areas, the absence of any public transport system (MoE, 2005), steady winds from eastern Europe and Saharan dust storms from the desert (Saliba et al., 2007). Therefore, the country represents a good case study for investigating air pollution in the region. The few measurements conducted in Beirut, the capital city of Lebanon, revealed high levels of nitrogen dioxide $\left(\mathrm{NO}_{2}\right)$ with an annual average concentration of $66 \mu \mathrm{g} \mathrm{m}^{-3}$ (Afif et al., 2009) and high levels of particulate matter, $\mathrm{PM}_{10}$ and $\mathrm{PM}_{2.5}$, with annual concentrations of 64 and $20 \mu \mathrm{g} \mathrm{m}^{-3}$, respectively (Massoud et al., 2011). The levels exceed World Health Organization (WHO) guideline values of $40 \mu \mathrm{g} \mathrm{m}^{-3}$ for $\mathrm{NO}_{2}$ and 20 and $10 \mu \mathrm{g} \mathrm{m}^{-3}$ for $\mathrm{PM}_{10}$ and $\mathrm{PM}_{2.5}$, respectively. Although these measurements provide valuable information on air pollution, they are scarce and limited to a few areas. Therefore, the use of chemical-transport models (CTM) is essential for understanding the spatio-temporal distribution of gaseous and particulate pollutants in the region. Previous studies have focused on simulating the distribution of $\mathrm{O}_{3}$ over this region using regional CTM. The EMAC chemistry general circulation model (Roeckner et al., 2006) was used to investigate $\mathrm{O}_{3}$ levels in the Persian gulf region (Leleiveld et al., 2009) and a fully coupled on-line model (WRF-Chem version 3.3.1) (Grell et al., 2005) was used for the Arabian Peninsula (Smoydzin et al., 2012). However, no modeling study has yet been conducted for Lebanon or its capital city Beirut. In this study, the WRF-ARW version 3.3 meteorological model (Skamarock et al., 2008) is used with the Polyphemus/Polair3D CTM (Mallet et al., 2007; Sartelet et al., 2007) to investigate air pollution in Beirut as well as in Lebanon from 2 to 18 July 2011. WRF has been evaluated against observations in many regions (Borge et al., 2008; Carvalho et al., 2012; Molders, 2008) but, to our knowledge, has never been applied to Lebanon. The Polyphemus/Polair3D CTM has been evaluated over Europe (Sartelet et al., 2007, 2012; Couvidat et al., 2012), Asia (Sartelet et al., 2008), and North America (Sartelet et al., 2012), but not in the Middle East region. This study aims to investigate air pollution in Beirut in July 2011 via meteorological and air quality modeling. The evaluation of WRF and Polyphemus/Polair3D in this region is essential prior to the use of such models for future air quality studies.

The methodology and the model configurations for WRF and Polyphemus/Polair3D are described in Sect. 2. The evaluation results for the meteorological and chemical simulations against observations are presented and discussed in Sects. 3 and 4, respectively. Conclusions and future prospects are provided in Sect. 5 .

\section{Method}

\subsection{Modeling domains}

For meteorological modeling, three modeling domains were set on a latitude-longitude projection. A mother domain (D3) with $25 \mathrm{~km}$ horizontal resolution covering the Middle East region, as well as some parts of eastern Europe, northern Africa and the Mediterranean Sea, and two nested domains with $5 \mathrm{~km}$ resolution for Lebanon (D2) and $1 \mathrm{~km}$ resolution for Beirut and its suburbs (D1) were adopted. The two nested domains D1 and D2 are used for the air quality model simulations. The nested mother domain (D3) was not used in the air quality model simulations due to the lack of an emission inventory at that resolution over the Middle East region.

\subsection{Episode selection and observational data set}

The modeling study was conducted from 2 to 18 July 2011 . During this period, meteorological and air quality measurements were conducted at the Faculty of Sciences of Saint Joseph University campus (USJ site) in the region of Mansourieh $\left(33.86^{\circ} \mathrm{N}, 35.56^{\circ} \mathrm{E}\right)$ distant by $6 \mathrm{~km}$ from the center of Beirut. The topography of Lebanon including that of the region surrounding the measurement site, is characterized by a coastal strip in the western part of the country and the Lebanon mountains and an inland plateau in the eastern part between the two mountain chains. The coastal region has a Mediterranean climate with land-sea breeze circulation. The eastern part presents continental characteristics. Meteorological measurements included wind speed (anemometer), wind direction (weather vane), surface temperature (thermometer), relative humidity (hygrometer) and atmospheric pressure (barometer). The average surface temperature during the measurement campaign was $25^{\circ} \mathrm{C}$; the temperature exceeded $28^{\circ} \mathrm{C}$ during 10 to 12 and 15 to 17 July 2011 . The average wind speed was $2 \mathrm{~m} \mathrm{~s}^{-1}$ during the measurement campaign with maximum wind speeds recorded during the day. The wind direction was mostly from the west during the day and from the east at night. Clear skies were dominant and no precipitation was recorded during the measurement period. These weather conditions, as well as westerly and easterly winds coming from Eastern Europe and Asia, respectively, favored oxidant and secondary organic aerosol (SOA) formation (Waked, 2012). Trace gases including carbon monoxide (CO), $\mathrm{NO}_{\mathrm{x}}$ and $\mathrm{O}_{3}$ were measured on-line on a $1 \mathrm{~min}$ basis using trace gas analyzers, while VOC were measured on a $1 \mathrm{~h}$ basis using an on-line Thermal Desorption Gas Chromatography with a Flame Ionization Detector (TD-GC-FID) and on a 5 min basis using a Proton Transfer Reaction Mass Spectrometry (PTRMS). However, only the results obtained from the TD-GC-FID are used for the evaluation of modeled VOC. $\mathrm{PM}_{2.5}$ samples were collected using a high-volume sampler $\left(30 \mathrm{~m}^{3} \mathrm{~h}^{-1}\right)$ on a $12 \mathrm{~h}$ basis (Waked, 2012). They were analyzed for OC and EC using the EUSAAR2 protocol (Cavalli 


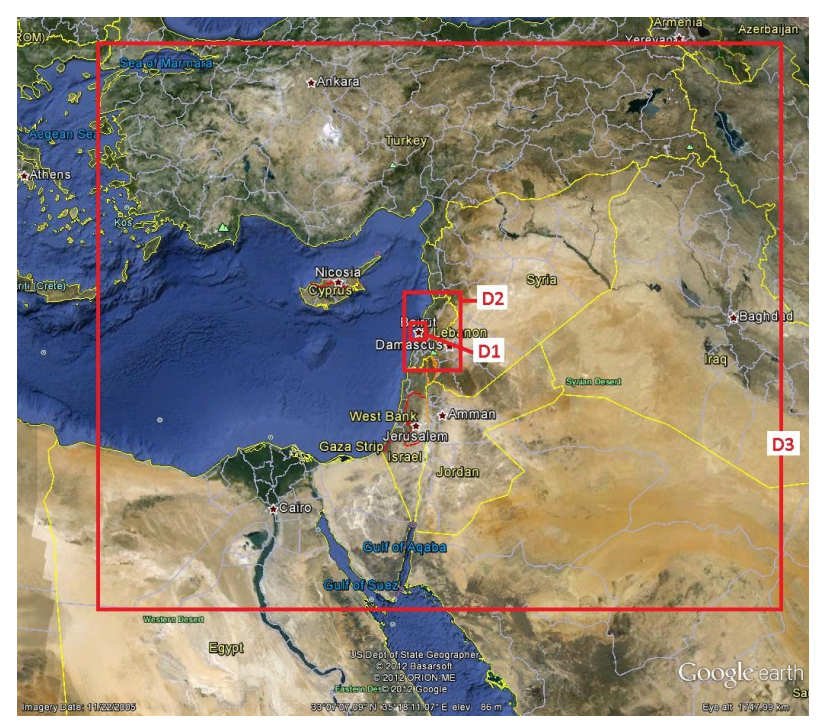

Fig. 1. The modeling domains D1, D2 and D3 used in this study.

et al., 2010), for organic aerosols using a gas chromatography coupled to a mass spectrometry (GC/MS) technique, and for inorganic aerosols using an ion chromatography (IC) technique. The model simulation results are compared with those measurements to evaluate the ability of the model to reproduce major chemical components of photochemical air pollution in Beirut.

\subsection{Meteorological modeling}

WRF-ARW was used to generate the meteorological fields using a two-way nesting approach with a vertical structure of 24 layers covering the whole troposphere. Initial and boundary conditions were driven by the National Centers for Environmental Prediction (NCEP) global tropospheric analyses with $1^{\circ} \times 1^{\circ}$ spatial resolution and $6 \mathrm{~h}$ temporal resolution. Topography and land use were interpolated from the United States Geological Survey (USGS) global land covers with the appropriate spatial resolution for each domain.

Physical parameterizations used in the model include the Kessler cloud microphysics scheme (Kessler, 1969), the Rapid Radiation Transfer Model (RRTM) long-wave radiation scheme (Mlawer et al., 1997), the Goddard NASA shortwave scheme (Chou and Suarez, 1994), the Grell-Devenyi ensemble cumulus parameterization scheme (Grell and Devenyi, 2002), and the Noah land surface model (Chen et al., 2001). These physical parameterizations have been used in several studies in the literature (Carvalho et al., 2012; Borge et al., 2008; Skamarock et al., 2008). Several physical options such as planetary boundary layer (PBL) dynamics, land surface model as well as several numerical options are available in WRF. A series of model experiments changing one option at a time were conducted to identify the simulation which provides the lowest biases and errors when compared to the observations. The options tested include restart time, PBL dynamics, and urban canopy parameterization. Because meteorological models tend to diverge after some integration time (typically two or three days), segmented simulations were also performed. Thus, several two-day restarted simulations were performed to complete an 18-day long simulation. For each simulation, the first $12 \mathrm{~h}$ period was considered as a spin-up period for the model. Because the PBL has an important impact on the near-surface wind field, two PBL schemes were tested: the Yunsai University (YSU) PBL scheme (Hong et al., 2006), which is a non-local closure scheme (Stull, 1988); and the Mellor-Yamada-NakanishiNiino (MYNN) level 2.5 scheme (Nakanishi and Niino, 2004), which is a local TKE-based scheme. The MYNN scheme was developed to improve performance of its original Mellor-Yamada model (Mellor and Yamada, 1974). Major differences between the two schemes (MYNN and MY) are the formulations of the mixing length scale and the method to determine unknown parameters. In addition, because the inner domain (D1) includes large urban areas, an urban surface model was used. WRF includes three urban surface models: the urban canopy model (UCM) (Kusaka et al., 2001), which is a single layer model, and two multi-layer models, the Building Environmental Parameterization (BEP) (Martilli et al., 2002) and the Building Energy Model (BEM) (Salamanca et al., 2010). In this study, UCM was used because it includes the anthropogenic heat release, which is not included in the multi-layer models (Kim, 2011). Using UCM, several influential parameters such as the anthropogenic heat flux, road width, and building width and height values typical for Beirut were chosen, whereas for other parameters (urban ratio for a grid, surface albedo of roof, road and wall, thermal conductivity of roof, road and wall, etc.), the values provided by the WRF configuration file were adopted because of a lack of data. Therefore, a reference building width of $11 \mathrm{~m}$ (CBDE, 2004) and a road width of $8.5 \mathrm{~m}$ were adopted (Chélala, 2008). A building height of $17.9 \mathrm{~m}$ was chosen (Chélala, 2008) while the mean annual anthropogenic heat flux (the heat released to the atmosphere as a result of human activities) for Beirut was estimated to be $17 \mathrm{~W} \mathrm{~m}^{-2}$ (IIASA, 2012).

\subsection{Air quality modeling}

The Polyphemus/Polair3D CTM was used. Aerosol modeling was performed using SIREAM (Size Resolved Aerosol Model) (Debry et al., 2007) coupled to the Hydrophilic/Hydrophobic Organic $\left(\mathrm{H}^{2} \mathrm{O}\right)$ model for SOA formation (Couvidat et al., 2012), ISORROPIA (Nenes et al., 1998) for inorganic aerosols thermodynamics, and the CB05 chemical kinetic mechanism for gas-phase chemistry (Yarwood et al., 2005; Kim et al., 2009, 2011). SIREAM segregates the particle size distribution into sections and solves the general dynamic equation by splitting coagulation and condensation/evaporation nucleation (Debry et al., 
2007). In $\mathrm{H}^{2} \mathrm{O}$, two anthropogenic and five biogenic SOA precursors species are used as surrogate precursors. In order to account for the fact that primary organic aerosols (POA) are semi-volatile organic compounds (SVOC), an SVOC/EIPOA (emissions inventory based POA) value of 5, which represents the ratio between SVOC and POA provided in the base emission inventory (Waked et al., 2012) was adopted following Couvidat et al. (2012) to estimate SVOC emissions. The sensitivity of $\mathrm{OC}$ concentrations to this ratio has been tested by Couvidat et al. (2012). A value of five has been shown to give satisfactory results in previous modeling studies (Couvidat et al., 2012, 2013) and, therefore, sensitivity to this model parameter was not tested here.

The USGS land cover was used. Initial and boundary conditions for the outer domain (D2) were extracted from the output of the Model for Ozone And Related chemical Tracers version 4 (MOZART-4; http://www.acd.ucar.edu/wrf-chem/ mozart.shtml), which is an off-line global tropospheric CTM (Emmons et al., 2010). It is driven by NCEP/NCAR reanalysis meteorology and uses emissions based on a database of surface emissions of ozone precursors (POET), Regional Emission Inventory in Asia (REAS) and Global Fire Emissions Database (GEFD2). The results are at $2.8^{\circ} \times 2.8^{\circ}$ horizontal resolution for 28 vertical levels. It should be noted that a pre-simulation was performed for the D1 (24 June to 2 July) and D2 (15 June to 2 July) domains to eliminate the effect of initial conditions. Outputs from the meteorological model (WRF-ARW) were used to compute vertical diffusion with the Troen and Mahrt (1986) and Louis (1979) parameterizations within the PBL. For horizontal diffusion, the CMAQ parameterization was used (Byun and Schere, 2006). Gas and particle deposition as well as sea-salt emissions were preprocessed using relevant meteorological variables. Biogenic emissions were calculated using the Model of Emissions of Gases and Aerosols from Nature (MEGAN V.2; Guenther et al., 2006). This model, which is designed for global and regional emission modeling, has a global coverage with a $1 \mathrm{~km}$ $\times 1 \mathrm{~km}$ resolution.

For anthropogenic emissions, a spatially resolved and temporally allocated emission inventory was developed for Lebanon as well as for Beirut and its suburbs in a previous study (Waked et al., 2012). This emission inventory is used here. Emissions were spatially allocated using a resolution of $5 \mathrm{~km}$ over Lebanon and a resolution of $1 \mathrm{~km}$ over Beirut. The inventory includes the emissions of $\mathrm{CO}, \mathrm{NO}_{\mathrm{x}}$, sulfur dioxide $\left(\mathrm{SO}_{2}\right)$, VOC, ammonia $\left(\mathrm{NH}_{3}\right), \mathrm{PM}_{10}$, and $\mathrm{PM}_{2.5}$. A wide variety of emission sources including road transport, maritime shipping, aviation, energy production, residential and commercial activities, industrial processes, agriculture, and solvent use are included in this inventory. A bottom-up methodology was used for the major contributing sources such as road transport, cement industries and power plant energy production. For other sources, a top-down approach was adopted. Spatial allocation was performed using population density maps, land cover and road network as well as
Table 1. Numerical options and physical parameterizations considered.

\begin{tabular}{llllll}
\hline Options & M1 & M2 & M3 & M4 & M5 \\
\hline UCM & no & yes & yes & no & no \\
PBL & YSU & YSU & MYNN & MYNN & YSU \\
Continuous simulations & yes & yes & yes & yes & no* \\
\hline
\end{tabular}

* Restarted every two days.

traffic count data and surveys in many regions (Waked and Afif, 2012). Temporal profiles were allocated with monthly, daily, and diurnal resolutions for all sources. The inventory was developed for a base year of 2010 .

\section{Meteorological simulations}

\subsection{Model simulation configurations}

The results obtained from WRF were evaluated with meteorological data collected at the USJ site. Reliable meteorological data at other locations were not available within the D1 and D2 domains, thereby preventing a more complete model performance evaluation. Different simulations from M1 to M5 (Table 1) were performed to select the meteorological simulation that has the lowest biases and errors when compared to observations.

For physical parameterizations, the YSU PBL scheme (simulation M2) and the MYNN scheme (simulation M3) were tested with the use of UCM. In addition, two simulations (M1 and M4) with the YSU and MYNN schemes, respectively, were performed without the use of UCM. To test numerical options, a simulation (M5) was performed using segmented simulations with two-day restarts to assess whether the model tends to diverge significantly after two days of simulation.

\subsection{Results}

To evaluate a model, several approaches can be used (Gilliam et al., 2006). Here, we compare model simulation results to measurements at one site using model performance statistical indicators that include the root mean square error (RMSE), mean fractional bias (MFB), mean fractional error (MFE), normalized mean bias (NMB), normalized mean error (NME), and the correlation coefficient. The results of the statistical evaluation for wind speed and wind direction at $10 \mathrm{~m}$ above ground level (a.g.l.), surface temperature, relative humidity, and pressure at $2 \mathrm{~m}$ a.g.l. are presented in Table 2 for the five simulations tested. Overall, the model is able to reproduce local wind speed, surface air temperature, and pressure with correlations greater than 0.74 (simulation M1). For wind direction and relative humidity, lower correlations $(0.2-0.4)$ are obtained. Wind speed and wind direction have values of MFB and NMB in the range of 20 to 
Table 2. Statistical performance evaluation of the meteorological variables for the WRF simulations.

\begin{tabular}{|c|c|c|c|c|c|c|}
\hline \multicolumn{7}{|l|}{ Wind speed } \\
\hline Simulation & $\operatorname{RMSE}\left(\mathrm{m} \mathrm{s}^{-1}\right)$ & MFB \% & MFE \% & $\mathrm{NMB} \%$ & NME \% & Correlation \\
\hline M1 & 1.34 & 34 & 50 & 43 & 55 & 0.74 \\
\hline M2 & 1.63 & 39 & 55 & 56 & 66 & 0.72 \\
\hline M3 & 1.54 & 32 & 56 & 45 & 62 & 0.63 \\
\hline M4 & 1.33 & 26 & 50 & 33 & 53 & 0.63 \\
\hline M5 & 1.43 & 35 & 54 & 45 & 60 & 0.55 \\
\hline \multicolumn{7}{|c|}{ Wind direction } \\
\hline Simulation & $\operatorname{RMSE}\left({ }^{\circ} \mathrm{C}\right)$ & MFB \% & MFE $\%$ & NMB $\%$ & NME \% & Correlation \\
\hline M1 & 92.06 & 23 & 41 & 21 & 35 & 0.38 \\
\hline M2 & 93.5 & 24 & 41 & 21 & 35 & 0.36 \\
\hline M3 & 94.23 & 20 & 41 & 19 & 34 & 0.39 \\
\hline M4 & 94.6 & 20 & 42 & 20 & 35 & 0.35 \\
\hline M5 & 132.48 & 35 & 62 & 44 & 61 & 0.23 \\
\hline \multicolumn{7}{|c|}{ Surface air temperature } \\
\hline Simulation & $\operatorname{RMSE}\left({ }^{\circ} \mathrm{C}\right)$ & MFB \% & MFE $\%$ & NMB $\%$ & NME \% & Correlation \\
\hline M1 & 1.54 & 5 & 5 & 5 & 5 & 0.9 \\
\hline M2 & 1.19 & 4 & 4 & 4 & 4 & 0.91 \\
\hline M3 & 0.88 & 2 & 3 & 2 & 3 & 0.91 \\
\hline M4 & 1.18 & 4 & 4 & 4 & 4 & 0.91 \\
\hline M5 & 1.47 & 3 & 5 & 3 & 5 & 0.84 \\
\hline \multicolumn{7}{|c|}{ Relative humidity } \\
\hline Simulation & RMSE (\%) & MFB \% & MFE \% & NMB \% & NME \% & Correlation \\
\hline M1 & 12.78 & 4 & 12 & 4 & 12 & 0.20 \\
\hline M2 & 13.46 & 5 & 13 & 5 & 13 & 0.14 \\
\hline M3 & 12.65 & 8 & 13 & 8 & 13 & 0.31 \\
\hline M4 & 12.17 & 7 & 12 & 7 & 12 & 0.33 \\
\hline M5 & 11.62 & 5 & 11 & 5 & 11 & 0.21 \\
\hline \multicolumn{7}{|c|}{ Atmospheric pressure } \\
\hline Simulation & RMSE (hPa) & MFB \% & MFE \% & NMB \% & NME \% & Correlation \\
\hline M1 & 13.83 & 1 & 1 & 1 & 1 & 0.98 \\
\hline M2 & 13.85 & 1 & 1 & 1 & 1 & 0.98 \\
\hline M3 & 14.01 & 1 & 1 & 1 & 1 & 0.97 \\
\hline M4 & 14 & 1 & 1 & 1 & 1 & 0.97 \\
\hline M5 & 13.96 & 1 & 1 & 1 & 1 & 0.88 \\
\hline
\end{tabular}

$60 \%$. For surface temperature, relative humidity, and pressure, the statistical biases indicate a low overprediction of 1 to $10 \%$. Accordingly, RMSE reported values for surface temperature $\left(1.54^{\circ} \mathrm{C}\right)$ and wind speed $\left(1.34 \mathrm{~m} \mathrm{~s}^{-1}\right)$ are low, those of relative humidity $(13 \%)$ and pressure $(14 \mathrm{hPa})$ are moderate, and that of wind direction is high $\left(92^{\circ}\right.$, simulation M1). Thus, model predictions of wind direction are the worst among the five variables. Other studies have shown RMSE values for surface temperature of $2.8^{\circ} \mathrm{C}$ in Alaska (Molders, 2008), $3.46^{\circ} \mathrm{C}$ in the southern US (Zhang et al., 2006), and $2.82^{\circ} \mathrm{C}$ in Paris (Kim, 2011). For wind speed, these values were $3 \mathrm{~m} \mathrm{~s}^{-1}$ in Portugal (Carvalho et al., 2012), $1.62 \mathrm{~m} \mathrm{~s}^{-1}$ in the southern US (Zhang et al., 2006), and $1.93 \mathrm{~m} \mathrm{~s}^{-1}$ in Paris (Kim, 2011). For wind direction, RMSE values of $92^{\circ}$ are comparable to the value obtained in the southern US $\left(97^{\circ}\right.$, Zhang et al., 2006), but greater than the value obtained in Portugal $\left(52^{\circ}\right.$, Carvalho et al., 2012). Therefore, this meteorological simulation shows satisfactory performance when compared to other similar studies. 


\subsection{Numerical options}

The evaluation of segmented simulations is reported in this section because grid nudging of the NCEP initial and boundary conditions was used in all simulations. Comparison between simulation M5 (segmented simulations with two-day restarts) and the other simulations (M1-M4) showed better correlations for all the variables for the long simulations without segmentation, especially for wind components where M5 gives correlations of 0.55 and 0.23 for wind speed and wind direction, respectively, compared to values of 0.74 and 0.38 obtained from a long simulation without segmentation such as M1. For other variables, differences between simulations are not significant. RMSE and other statistical indicator values are comparable between M5 and the continuous simulations. This leads to the conclusion that the model does not diverge significantly after some integration time, which results in part from the small size of the D1 domain and its two-way nesting to greater domains. On the other hand, there is considerable uncertainty in the initial conditions, which are generated every two days in the noncontinuous simulations because these initial conditions are provided with a spatial grid spacing of $100 \mathrm{~km}$ to be used in a simulation for Beirut with a grid spacing resolution of $1 \mathrm{~km}$, thereby leading to biases and errors that are higher than those of a continuous simulation.

\subsection{Physical parameterizations}

The MYNN PBL scheme used with UCM (simulation M3) was found to produce the best statistical results for all the variables. Accordingly, this physical option influences wind speed, surface temperature, relative humidity, and pressure. Using this option leads to the best correlations among all the simulations for all variables except for wind speed. The correlations are $0.63,0.39,0.91,0.31$, and 0.97 for wind speed, wind direction, surface temperature, relative humidity, and pressure. For MFB, MFE, NMB and NME, no significant differences are observed among these simulations (M1-M4). In summary, M1 with the YSU scheme gives the best results for wind speed and M3 with the MYNN scheme and UCM gives the best results for wind direction and relative humidity.

\subsection{Best configuration}

Temporal variations for wind speed, wind direction, surface temperature, and relative humidity of the two best selected simulations (M1 and M3) are shown from 2 July, 00:00 LT to 17 July, 00:00, 2011 in Fig. 2 because no observations were recorded after 17 July 00:00. The model reproduces wind direction better from 6 July to 10 July in both simulations while from 2 July to 6 July and from 12 to 16 July, the model is not able to reproduce winds originating from the East. The model reproduces satisfactorily relative humidity for the se-
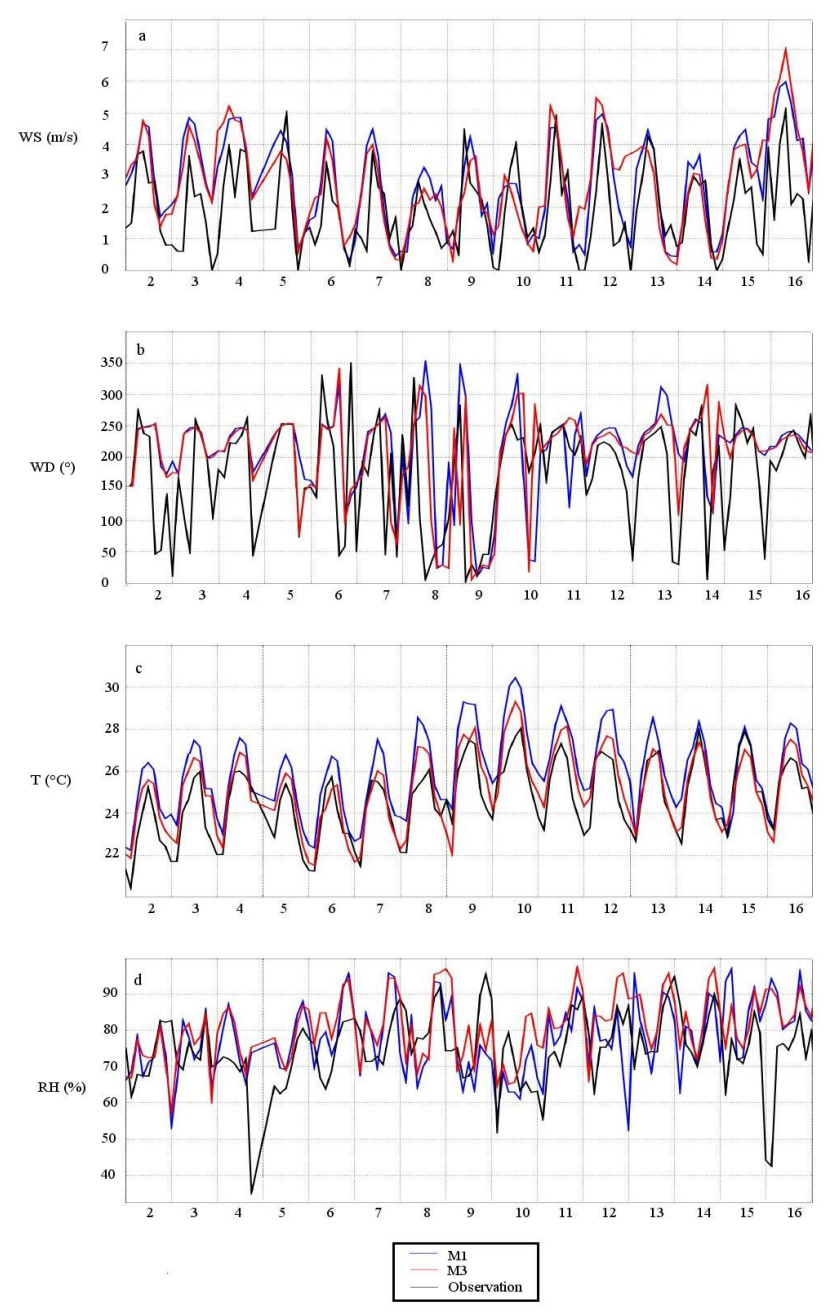

Fig. 2. Temporal variation of meteorological variables (observations and model simulations M1 and M3) from 2 to 17 July 2011; (a) wind speed $\left(\mathrm{m} \mathrm{s}^{-1}\right)$; (b) wind direction $\left({ }^{\circ}\right)$; (c) air temperature $\left({ }^{\circ} \mathrm{C}\right)$; (d) relative humidity $(\%)$ ).

lected period in simulations except on 4, 5, 15 and 16 July when the model overpredicts relative humidity. Surface temperature is better reproduced in simulation M3 than in simulation M1, which overpredicts surface temperature. Lastly, a comparable pattern is observed with lower values for wind speed in simulation M3 due to the use of UCM, which has an effect of decreasing wind speeds due to urbanization. In summary, the model performs better from 6 to 10 July for all the variables.

Clearly, the PBL scheme influences wind speed, wind direction, and surface temperature (Borge et al., 2008). Temperature is best modeled with the MYNN scheme using UCM. This result agrees with that obtained by Kim (2011) in a simulation over Paris, France. Outside the center of the city, the effect of UCM on temperature is not significant and is compensated by the effect of the PBL scheme. For wind 
Table 3. Results from simulations A1 to A4 from 2 to 18 July 2011 at USJ.

\begin{tabular}{lcccc}
\hline & $\begin{array}{c}\mathrm{O} 3 \\
\text { Mean concentration } \\
\left(\mu \mathrm{g} \mathrm{m}^{-3}\right)\end{array}$ & $\begin{array}{c}\mathrm{CO} \\
\text { Mean concentration } \\
\left(\mu \mathrm{g} \mathrm{m}^{-3}\right)\end{array}$ & $\begin{array}{c}\mathrm{NO}_{\mathrm{x}} \\
\text { Mean concentration } \\
\left(\mu \mathrm{g} \mathrm{m}^{-3}\right)\end{array}$ & $\begin{array}{c}\mathrm{PM}_{2.5} \\
\text { Mean concentration } \\
\left(\mu \mathrm{g} \mathrm{m}^{-3}\right)\end{array}$ \\
\hline Observations at USJ & 51 & 519 & 65 & 22 \\
A1 (base simulation) & 95 & 703 & 69 & 21 \\
$\mathrm{~A} 2\left(\mathrm{NO}_{\mathrm{x}}\right.$ emissions halved) & 136 & 702 & 31 & 22 \\
$\mathrm{~A} 3\left(\mathrm{VOC}^{-3}\right.$ emissions halved) & 82 & 702 & 72 & 19 \\
$\mathrm{~A} 4\left(\mathrm{O}_{3}\right.$ boundary conditions halved) & 50 & 703 & 68 & 20 \\
\hline
\end{tabular}

speed and wind direction, no significant variation is observed between M1 and M3. For relative humidity, a better correlation is obtained using the MYNN PBL scheme, and a lower non-significant correlation is obtained for wind speed. Overall, simulation M3 performs slightly better for most variables than simulation M1 particularly for temperature and humidity and we may consider that the correlation of 0.63 obtained for wind speed in simulation M3 is close to the correlation of 0.74 (systematic error of $18 \%$ ) obtained in simulation M1 while the correlation for relative humidity of 0.31 obtained in simulation M3 is significantly different from the value of 0.2 (systematic error of $43 \%$ ) obtained in simulation M1. In addition, surface air temperature and wind direction were slightly better modeled in simulation M3 in terms of temporal variation (Fig. 2) and NMB (Table 2). Based on these considerations, the results obtained from simulation M3 are used for air quality modeling.

\section{Air quality simulations}

The results obtained from Polyphemus/Polair3D were evaluated against measurements of gaseous species $\left(\mathrm{O}_{3}, \mathrm{NO}_{2}\right.$, VOC and $\mathrm{CO}$ ) and $\mathrm{PM}_{2.5}$ (total mass and major components) collected at the USJ site. Statistical indicators used for model evaluation include MFB, MFE, mean normalized bias (MNB), and mean normalized error (MNE) (e.g., Yu et al., 2006).

\subsection{Gaseous species}

The base simulation conducted with the MOZART-4 boundary conditions (Simulation $\mathrm{A} 1$ ) led to $\mathrm{O}_{3}$ concentrations within the D1 domain that were too high compared to the observations by nearly a factor of two (see Table 3 ). Sensitivity simulations were conducted where emissions of $\mathrm{NO}_{\mathrm{x}}(\mathrm{Simu}-$ lation A2) and VOC (Simulation A3) were reduced by a factor of two; these simulations did not lead to satisfactory $\mathrm{O}_{3}$ concentrations, in part because of the strong influence of the boundary conditions. A decrease of $\mathrm{NO}_{\mathrm{x}}$ emissions leads to an increase in $\mathrm{O}_{3}$ concentrations (A2) because the study area is saturated in $\mathrm{NO}_{\mathrm{x}}$. Moreover, $\mathrm{NO}_{\mathrm{x}}$ concentrations are well reproduced by the model in the base simulation $\mathrm{A} 1$. VOC reductions are effective in reducing $\mathrm{O}_{3}$ concentrations (A3) due to the fact that the area of the study is considered to be VOC-limited, having a VOC to $\mathrm{NO}_{\mathrm{x}}$ ratio in the range of 3 to 5. However, the decrease in $\mathrm{O}_{3}$ concentrations is insufficient to match the observed concentrations and VOC concentrations are already underestimated by the model in A1 by a factor of 2 to 3 (Table 4). An increase of $\mathrm{NO}_{\mathrm{x}}$ emissions and a decrease of VOC emissions could lead to satisfactory $\mathrm{O}_{3}$ concentrations, but would lead to non-satisfactory results for VOC and $\mathrm{NO}_{\mathrm{x}}$ modeled concentrations. Therefore, a sensitivity simulation was also conducted with the boundary $\mathrm{O}_{3}$ concentrations halved (Simulation A4). That simulation led to reasonable agreement with the observations for all gaseous species. A comparison between simulation A1 and simulation $\mathrm{A} 4$ shows that modifying the $\mathrm{O}_{3}$ boundary concentrations has negligible effect on $\mathrm{CO}, \mathrm{NO}_{\mathrm{x}}$ and $\mathrm{PM}_{2.5}$ modeled concentrations. Although a recent evaluation of MOZART-4 with ozone study led to satisfactory results (Emmons et al., 2010), a detailed evaluation with $\mathrm{PBL} \mathrm{O}_{3}$ data in the Middle East region has not been conducted because of a lack of data. Better characterization of PBL air pollution concentrations in that region is needed to obtain realistic $\mathrm{O}_{3}$ boundary concentrations.

This strong influence of boundary conditions, which leads to a significant overestimation of $\mathrm{O}_{3}$ concentrations, may be due to the fact that the MOZART-4 data used during this study have a horizontal resolution of $280 \mathrm{~km}$ and are used as boundary conditions for a domain D2 with a horizontal resolution of $5 \mathrm{~km}$. It is possible that the use of an intermediate domain of 25 or $50 \mathrm{~km}$ horizontal resolution may decrease the uncertainties generated by the MOZART-4 data. However, an emission inventory for the Middle East region is not currently available and the use of an intermediate domain D3 for air quality simulation is, therefore, not feasible.

In addition, we compared the results of this simulation to $\mathrm{O}_{3}$ concentrations measured in the summer of 2004 in Beirut at an urban site $\left(33.88^{\circ} \mathrm{N}, 35.48^{\circ} \mathrm{E}\right.$; Saliba et al., 2006) in order to assess the accuracy of the simulation at a different location than the one where the measurements are performed. Such comparisons are not true evaluations of the model because the years of the simulation and observations differ. Nevertheless, such comparisons may point to some 
Table 4. Statistical performance evaluation for $\mathrm{O}_{3}, \mathrm{NO}_{2}, \mathrm{NO}_{\mathrm{x}}, \mathrm{CO}$ and some VOC at USJ for the simulation A1.

\begin{tabular}{lllrrrr}
\hline Species & $\begin{array}{l}\text { Observed } \\
\text { mean }\left(\mu \mathrm{g} \mathrm{m}^{-3}\right)\end{array}$ & $\begin{array}{l}\text { Modeled } \\
\text { mean }\left(\mu \mathrm{g} \mathrm{m}^{-3}\right)\end{array}$ & MFB & MFE & MNB & MNE \\
\hline $\mathrm{O}_{3}^{\mathrm{a}}$ & 51 & 95 & $32 \%$ & $57 \%$ & $58 \%$ & $74 \%$ \\
$\mathrm{NO}_{\mathrm{x}}$ & 65 & 69 & $14 \%$ & $113 \%$ & $70 \%$ & $104 \%$ \\
$\mathrm{NO}_{2}$ & 54 & 63 & $40 \%$ & $111 \%$ & $33 \%$ & $70 \%$ \\
$\mathrm{CO}$ & 519 & 703 & $24 \%$ & $41 \%$ & $72 \%$ & $88 \%$ \\
$\mathrm{TOL}$ & $19^{\mathrm{b}}$ & $7^{\mathrm{c}}$ & $-98 \%$ & $100 \%$ & $-61 \%$ & $65 \%$ \\
$\mathrm{XYL}$ & $17^{\mathrm{d}}$ & $8^{\mathrm{e}}$ & $-86 \%$ & $93 \%$ & $-50 \%$ & $62 \%$ \\
$\alpha$-Pinene & 0.05 & $0.06^{\mathrm{f}}$ & $-23 \%$ & $77 \%$ & $-169 \%$ & $247 \%$ \\
Isoprene & 0.62 & 0.4 & $-53 \%$ & $116 \%$ & $-20 \%$ & $110 \%$ \\
\hline
\end{tabular}

a A threshold value of $80 \mu \mathrm{g} \mathrm{m}^{-3}$ was used for observations.

b The "TOL" measured species include toluene, ethylbenzene, butylbenzene, isopropylbenzene and propylbenzene.

c The "TOL" modeled species includes also other minor monosubstituted aromatics.

d The "XYL" measured species includes xylene, trimethylbenzenze and ethyltoluene.

e The "XYL" modeled species includes also other minor polysubstituted aromatics.

f The " $\alpha$-pinene" modeled species includes $\alpha$-pinene and sabinene.

possible biases in the air quality simulation if the differences cannot be justified. The results show a modeled value of $1585 \mu \mathrm{g} \mathrm{m}^{-3}$ for CO in both simulations A1 and A4 compared to a measured value of $1213 \mu \mathrm{g} \mathrm{m}^{-3}$. For $\mathrm{PM}_{10}$, a value of $47 \mu \mathrm{g} \mathrm{m}^{-3}$ was modeled in both simulations compared to a measured value of $44 \mu \mathrm{g} \mathrm{m}^{-3}$. The modeled $\mathrm{O}_{3}$ concentrations are $54 \mu \mathrm{g} \mathrm{m}^{-3}$ in simulation $\mathrm{A} 1$ and $32 \mu \mathrm{g} \mathrm{m}^{-3}$ in simulation A4, compared to a measured value of $34 \mu \mathrm{g} \mathrm{m}^{-3}$. Clearly, the results obtained from this evaluation show that simulation $\mathrm{A} 4$ with modified $\mathrm{O}_{3}$ boundary conditions leads to better results for $\mathrm{O}_{3}$ concentrations and has negligible effect on other pollutants. The results obtained from simulations A1 and A4 are presented and evaluated against measurements below.

Average modeled surface concentrations (over both land and sea) of $\mathrm{O}_{3}, \mathrm{NO}_{2}$, and $\mathrm{CO}$ from 2 to 18 July are 50, 49 and $700 \mu \mathrm{g} \mathrm{m}^{-3}$ in the inner domain (D1) and 72, 10 and $240 \mu \mathrm{g} \mathrm{m}^{-3}$ in the outer domain (D2), respectively, in simulation A4. In simulation A1, average modeled surface concentrations for $\mathrm{O}_{3}$ were 125 and $103 \mu \mathrm{g} \mathrm{m}^{-3}$ for the domains D2 and D1, respectively. For other gaseous pollutants such as $\mathrm{NO}_{2}\left(58 \mu \mathrm{g} \mathrm{m}^{-3}\right.$ for D2 and $10 \mu \mathrm{g} \mathrm{m}^{-3}$ for D1) and CO ( $768 \mu \mathrm{g} \mathrm{m}^{-3}$ for D2 and $245 \mu \mathrm{g} \mathrm{m}^{-3}$ for D1), modeled concentrations were comparable between simulations A1 and A4.

The modeled values for $\mathrm{O}_{3}$ and $\mathrm{NO}_{2}$ in the inner domain (simulation A4) are comparable to the average annual modeled values of $47 \mu \mathrm{g} \mathrm{m}^{-3}$ and $52 \mu \mathrm{g} \mathrm{m}^{-3}$ for $\mathrm{O}_{3}$ and $\mathrm{NO}_{2}$, respectively, obtained in a modeling study over the Iberian Peninsula in the northwestern Mediterranean region for a base year of 2004 using a coupled WRF/CMAQ model (Jimenéz-Guerrero et al., 2008).

The modeled surface spatial distributions of $\mathrm{O}_{3}$ and $\mathrm{NO}_{2}$ concentrations for D2 and D1 (Figs. 3 and 4) show lower $\mathrm{O}_{3}$ concentrations where most $\mathrm{NO}_{\mathrm{x}}$ emissions from industries, harbors and road traffic occur and higher values in the mountains. Accordingly, higher concentrations of $\mathrm{NO}_{2}$ are modeled near the coast in Beirut and its suburbs, in the cities of Tripoli and Chekka in the north and Jieh in the south. Major sources in those areas include dense traffic in urban areas and on highways along the coast, in particular in Beirut and Tripoli, the Zouk power plant located on the coast north of Beirut, the Jieh power plant and the cement plants located in the city of Chekka. Other emissions are generated from the harbors in Beirut and Tripoli and from the international airport located on the coast south of Beirut. Higher $\mathrm{O}_{3}$ concentrations modeled in the mountains (east of the domain) might be related to a higher $\mathrm{VOC} / \mathrm{NO}_{\mathrm{x}}$ ratio (Fig. 5), which is more favorable to $\mathrm{O}_{3}$ formation.

To evaluate the model concentration results at the USJ site, different statistical metrics were calculated for the 2-18 July period, as shown in Table 4 for the simulation A1 and in Table 5 for the simulation A4.

The model reproduces satisfactorily $\mathrm{O}_{3}$ concentrations in simulation A4 (bias in the range of 9 to $17 \%$ ). MNB and MNE values for $\mathrm{O}_{3}$ of $-9 \%$ and $33 \%$, respectively, are within suggested performance criteria (Russel and Denis, $2000)$ of $\pm 5-15 \%$ for MNB and $30-35 \%$ for MNE. However, in simulation $\mathrm{A} 1, \mathrm{O}_{3}$ concentrations are significantly overestimated; MNB and MNE values of 58 and $74 \%$, respectively, are not within the range of the suggested performance criteria. The mean $\mathrm{NO}_{2}$ concentration is well reproduced by the model but the hourly concentrations show a positive bias. For $\mathrm{NO}_{2}$, the MNB values of 33 (simulation A1) and $42 \%$ (simulation A4) are comparable to the reported value of $35 \%$ obtained during a simulation in the North Sea coastal region in Europe in July 2001 (Matthias et al., 2008) and to the daytime and nighttime values of $-19 \%$ and $31 \%$ reported in Mexico City during the MCMA2006/MILAGRO field campaign (Zhang et al., 2009). The MFB values of $16 \%$ (simulation A4) for $\mathrm{NO}_{2}$ in Beirut is also commensurate with the MFB value of $15 \%$ calculated in 

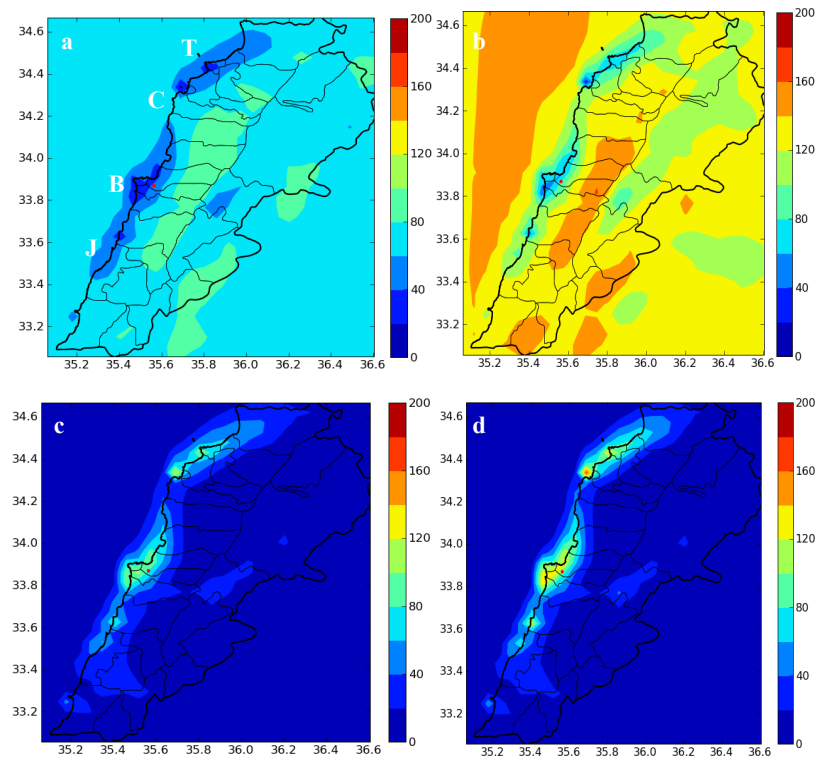

Fig. 3. Modeled average $\mathrm{O}_{3}$ concentrations ((a) simulation $\mathrm{A} 1$ and (b) simulation $\mathrm{A} 4)$ and $\mathrm{NO}_{2}$ concentrations ((c) simulation $\mathrm{A} 1$ and (d) simulation A4) in $\mu \mathrm{g} \mathrm{m}^{-3}$ for the outer domain D2 ( $\mathrm{T}=$ Tripoli; $\mathrm{C}=$ Chekka; $\mathrm{B}=$ Beirut; $\mathrm{J}=\mathrm{Jieh}$ ).

a modeling study at the Iberian Peninsula over the Mediterranean basin with the use of a different CTM model (Jimenéz-Guerrero et al., 2008). However, the value of $40 \%$ obtained in simulation A1 is greater by nearly a factor of two, because of the $\mathrm{O}_{3}$ overestimation. However, MNB values of $74 \%$ (simulation $\mathrm{A} 4$ ) and $70 \%$ (simulation $\mathrm{A} 1$ ) for $\mathrm{NO}_{\mathrm{x}}$ calculated during this study are in better agreement with observations than the reported value of $101 \%$ for a simulation over Nashville, USA, in July 1999 using the CMAQ model (Bailey et al., 2007). CO concentrations show an overprediction by the model on the order of $30 \%$ on average. These results are comparable to those of other studies conducted in Europe, Mexico and the USA (Matthias et al., 2008; Zhang et al., 2009; Bailey et al., 2007). In contrast, CO modeled average concentrations in Spain were underpredicted by the model with an MFB value of $-26 \%$ (Jimenéz-Guerrero et al., 2008) with the same order of magnitude as those calculated MFB for Beirut (20\% and 24\%; Tables 4 and 5).

Biogenic VOC concentrations are small $\left(<1 \mu \mathrm{g} \mathrm{m}^{-3}\right)$ for both observations and simulations; they show an overprediction of $\alpha$-pinene by the model by a factor of two in simulation A4 and a good agreement between modeled and measured values in simulation A1 due to the fact that VOC such as $\alpha$ pinene may be consumed in the simulation $\mathrm{A} 1$ to form $\mathrm{O}_{3}$ because the inner domain D2 is VOC limited. For isoprene, an underprediction on the order of $30 \%$ was calculated. The overprediction of $\alpha$-pinene in simulation A4 could be related to the fact that $\alpha$-pinene model species is a surrogate species that includes $\alpha$-pinene and sabinene. The MNB values of -20 and $-14 \%$ (Tables 4 and 5) reported for isoprene are
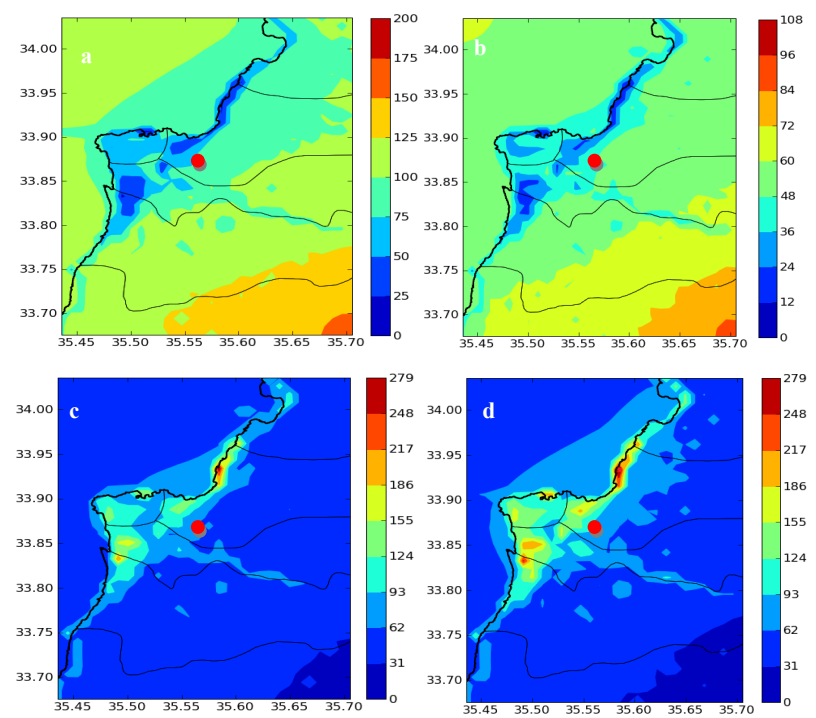

Fig. 4. Modeled average $\mathrm{O}_{3}$ concentrations ((a) simulation $\mathrm{A} 1$ and (b) simulation A4) and $\mathrm{NO}_{2}$ concentrations ((c) simulation $\mathrm{A} 1$ and (d) simulation A4) in $\mu \mathrm{g} \mathrm{m}^{-3}$ for the inner domain D2. The red dot corresponds to the location of the measurement site at USJ during July 2011

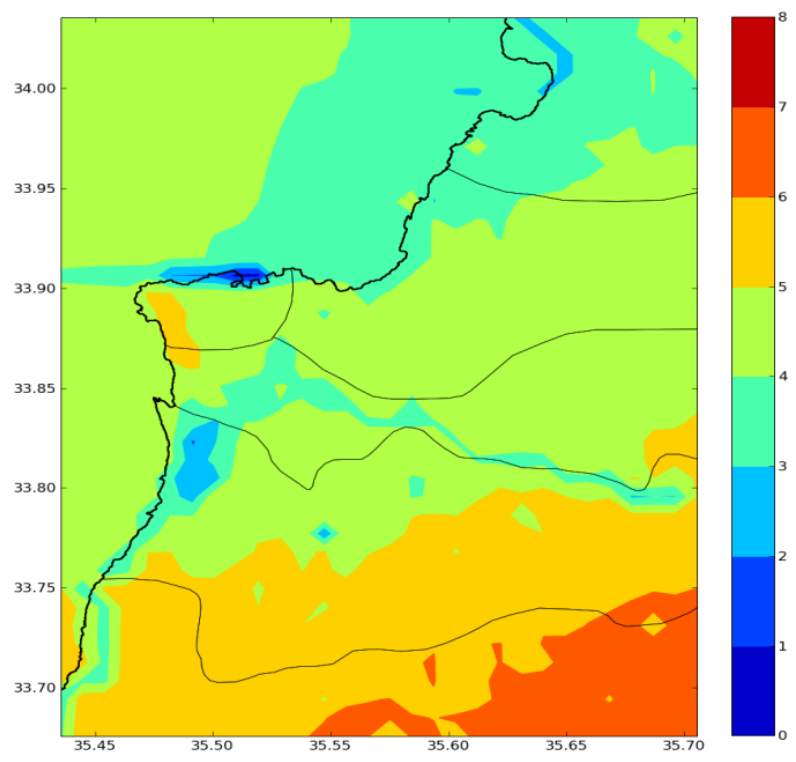

Fig. 5. Modeled average $\mathrm{VOC} / \mathrm{NO}_{\mathrm{x}}$ ratio for the inner domain $\mathrm{D} 1$.

comparable to the reported values of $14 \%$ and $-17 \%$ during a simulation in July 2004 using the MOZART-4 CTM (Horowitz et al., 2007). Anthropogenic VOC such as toluene and xylene are underestimated by the model by a factor of 2 to 3 . Nevertheless, the results obtained are satisfactory because speciated VOC emissions are associated with large uncertainties and modeled VOC concentrations, which are typically not evaluated, are subject to significant bias. Indeed, 
Table 5. Statistical performance evaluation for $\mathrm{O}_{3}, \mathrm{NO}_{2}, \mathrm{NO}_{\mathrm{x}}, \mathrm{CO}$ and some VOC at USJ for the simulation A4.

\begin{tabular}{lllrrrr}
\hline Species & $\begin{array}{l}\text { Observed } \\
\text { mean }\left(\mu \mathrm{g} \mathrm{m}^{-3}\right)\end{array}$ & $\begin{array}{l}\text { Modeled } \\
\text { mean }\left(\mu \mathrm{g} \mathrm{m}^{-3}\right)\end{array}$ & MFB & MFE & MNB & MNE \\
\hline $\mathrm{O}_{3}^{\mathrm{a}}$ & 51 & 50 & $-17 \%$ & $33 \%$ & $-9 \%$ & $33 \%$ \\
$\mathrm{NO}_{\mathrm{x}}$ & 65 & 69 & $27 \%$ & $118 \%$ & $74 \%$ & $108 \%$ \\
$\mathrm{NO}_{2}$ & 54 & 54 & $16 \%$ & $105 \%$ & $42 \%$ & $76 \%$ \\
$\mathrm{CO}$ & 519 & 703 & $20 \%$ & $41 \%$ & $55 \%$ & $73 \%$ \\
$\mathrm{TOL}$ & $19^{\mathrm{b}}$ & $7^{\mathrm{c}}$ & $-96 \%$ & $97 \%$ & $-61 \%$ & $62 \%$ \\
$\mathrm{XYL}$ & $17^{\mathrm{d}}$ & $8^{\mathrm{e}}$ & $-87 \%$ & $89 \%$ & $-55 \%$ & $58 \%$ \\
$\alpha$-Pinene & 0.05 & $0.1^{\mathrm{f}}$ & $37 \%$ & $97 \%$ & $261 \%$ & $301 \%$ \\
Isoprene & 0.62 & 0.4 & $-94 \%$ & $122 \%$ & $-14 \%$ & $109 \%$ \\
\hline
\end{tabular}

${ }^{\mathrm{a}} \mathrm{A}$ threshold value of $80 \mu \mathrm{g} \mathrm{m}^{-3}$ was used for observations.

b The "TOL" measured species include toluene, ethylbenzene, butylbenzene, isopropylbenzene and propylbenzene.

"The "TOL" modeled species includes also other minor monosubstituted aromatics.

${ }^{\mathrm{d}}$ The "XYL" measured species includes xylene, trimethylbenzenze and ethyltoluene.

e The "XYL" modeled species includes also other minor polysubstituted aromatics.

f The " $\alpha$-pinene" modeled species includes $\alpha$-pinene and sabinene.

Table 6. Statistical performance evaluation for $\mathrm{PM}_{2.5}$, OC, EC and particulate sulfate, nitrate and ammonium at USJ for the simulation A1.

\begin{tabular}{lrrrrr}
\hline Species & $\begin{array}{r}\text { Observed } \\
\text { mean }\left(\mu \mathrm{g} \mathrm{m}^{-3}\right)\end{array}$ & $\begin{array}{r}\text { Modeled } \\
\text { mean }\left(\mu \mathrm{g} \mathrm{m}^{-3}\right)\end{array}$ & $\begin{array}{r}\mathrm{RMSE} \\
\left(\mu \mathrm{g} \mathrm{m}^{-3}\right)\end{array}$ & MFB & MFE \\
\hline $\mathrm{PM}_{2.5}$ & 21.9 & 21.32 & 9.75 & $-19 \%$ & $38 \%$ \\
OC & 5.6 & 3.31 & 3.32 & $-62 \%$ & $65 \%$ \\
EC & 1.8 & 1.22 & 1.06 & $-33 \%$ & $56 \%$ \\
Sulfate & 6.06 & 8.10 & 5.35 & $26 \%$ & $61 \%$ \\
Nitrate & 0.32 & 0.008 & 0.39 & $-186 \%$ & $186 \%$ \\
Ammonium & 1.87 & 0.32 & 1.9 & $-113 \%$ & $128 \%$ \\
\hline
\end{tabular}

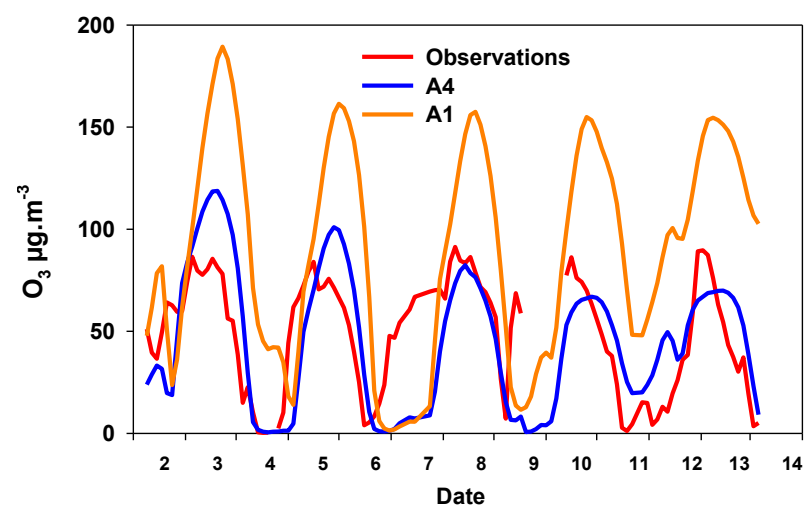

Fig. 6. Temporal variation of observed and modeled $\mathrm{O}_{3}$ concentrations in $\mu \mathrm{g} \mathrm{m}^{-3}$ from 2 to 13 July 2011 .

monoterpene concentrations are underestimated by almost a factor of two in a simulation over the eastern US using the MOZART-4 CTM (Horowitz et al., 2007) due to a significant underestimation in terpene emissions while isoprene emission estimates can differ by more than a factor of 3 for specific times and locations when different driving variables are used in the emissions calculations (Guenther et al., 2006).

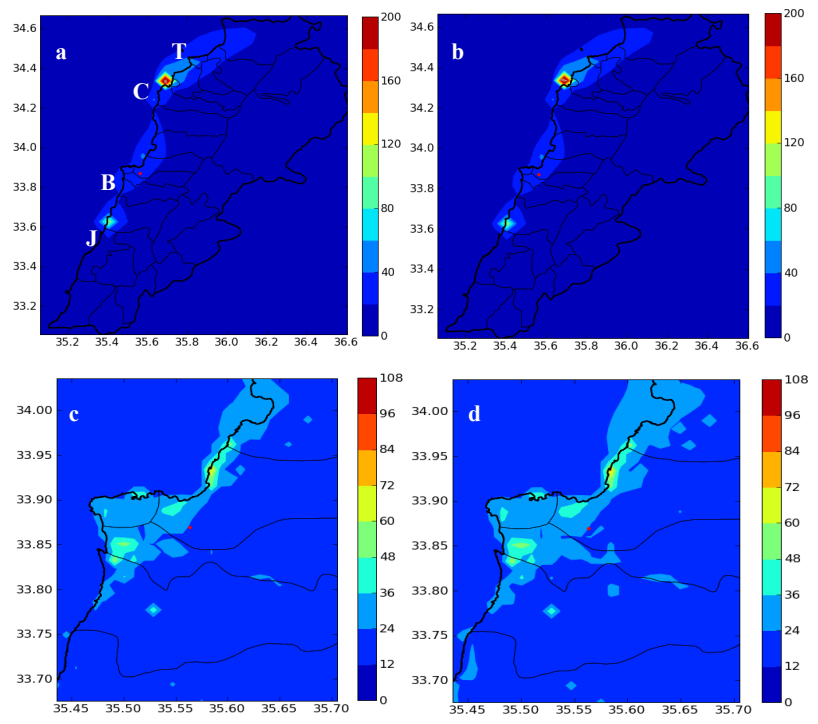

Fig. 7. Modeled average $\mathrm{PM}_{2.5}$ concentrations in $\mu \mathrm{g} \mathrm{m}^{-3}$ in Lebanon ((a) simulation A1 and (b) simulation A4) and in the city of Beirut and its suburbs ((c) simulation A1 and (d) simulation A4). ( $\mathrm{T}=$ Tripoli; $\mathrm{C}=$ Chekka $; \mathrm{B}=$ Beirut $; \mathrm{S}=$ Sibline $)$. 
Table 7. Statistical performance evaluation for $\mathrm{PM}_{2.5}$, OC, EC and particulate sulfate, nitrate and ammonium at USJ for the simulation A4.

\begin{tabular}{lrrrrr}
\hline Species & $\begin{array}{r}\text { Observed } \\
\text { mean }\left(\mu \mathrm{g} \mathrm{m}^{-3}\right)\end{array}$ & $\begin{array}{r}\text { Modeled } \\
\text { mean }\left(\mu \mathrm{g} \mathrm{m}^{-3}\right)\end{array}$ & $\begin{array}{r}\text { RMSE } \\
\left(\mu \mathrm{g} \mathrm{m}^{-3}\right)\end{array}$ & MFB & MFE \\
\hline $\mathrm{PM}_{2.5}$ & 21.9 & 19.93 & 9.89 & $-21 \%$ & $39 \%$ \\
$\mathrm{OC}$ & 5.6 & 3.24 & 2.93 & $-59 \%$ & $61 \%$ \\
$\mathrm{EC}$ & 1.8 & 1.17 & 1.05 & $-33 \%$ & $56 \%$ \\
Sulfate & 6.06 & 7.35 & 5.35 & $25 \%$ & $61 \%$ \\
Nitrate & 0.32 & 0.0049 & 0.39 & $-189 \%$ & $189 \%$ \\
Ammonium & 1.87 & 0.32 & 1.9 & $-114 \%$ & $128 \%$ \\
\hline
\end{tabular}

Temporal variations for $\mathrm{O}_{3}$ are shown in Fig. 6 from 2 to 13 July 2011 (no measurements were recorded after 13 July). The model reproduces satisfactorily the diurnal variation of $\mathrm{O}_{3}$, with a peak $\mathrm{O}_{3}$ concentration occurring between 12 p.m. and 1 p.m. for both observed and modeled values on most days. This day peak is typical for $\mathrm{O}_{3}$ and was observed in many modeling studies of air pollution and measurements and is related to the formation of $\mathrm{O}_{3}$ during the day from precursors such as $\mathrm{NO}_{\mathrm{x}}, \mathrm{CO}$ and VOC in the presence of intense solar radiation. However, on some days $(3,5$, and 8 July), a second nonsignificant $\mathrm{O}_{3}$ peak is observed between $9 \mathrm{a} . \mathrm{m}$. and $10 \mathrm{a} . \mathrm{m}$. This second peak is not reproduced by the model. The observed peak could be related in part to variability in the measured $\mathrm{O}_{3}$ concentrations (fluctuations) during a wide peak period. This second peak could also be related to the road traffic diurnal variations when vehicle emissions decrease slowly during the day time peak between 10 a.m. and 11 a.m. (Waked and Afif, 2012; Waked et al., 2012) and, therefore, account for a decrease in $\mathrm{O}_{3}$ formation. Although the diurnal variations of road traffic are included in this modeling study, the tendency of the model to normalize these fluctuations during the $\mathrm{O}_{3}$ peak and the uncertainties associated with wind directions on some days could contribute to the discrepancy between the observations and the model.

\subsection{Particulate pollutants}

Modeled $\mathrm{PM}_{2.5}$ average surface concentrations (over both land and sea) from 2 to 18 July 2011 are $10 \mu \mathrm{g} \mathrm{m}^{-3}$ (simulations A1 and A4) for Lebanon (D2) and 21 and $19 \mu \mathrm{g} \mathrm{m}^{-3}$ (simulations A1 and A4) for Beirut and its suburbs (D1). The spatial distribution of $\mathrm{PM}_{2.5}$ concentrations (Fig. 7) shows higher concentrations $\left(>40 \mu \mathrm{g} \mathrm{m}^{-3}\right)$ in the city of Beirut and its northern suburb, Chekka in the north and Sibline in the south. Dense on-road traffic, industrial sources (Zouk plant north of Beirut and the cement plants near the coast of Chekka and Sibline) and Beirut international airport located south of Beirut lead to significant air pollutant emissions (Waked et al., 2012). Lower $\mathrm{PM}_{2.5}$ concentrations in the eastern part of the domains $\left(<20 \mu \mathrm{g} \mathrm{m}^{-3}\right)$, are related to the fact that anthropogenic sources in these areas are less significant. This suggests that $\mathrm{PM}_{2.5}$ concentrations are dominated by anthropogenic sources. Indeed, biogenic modeled
SOA account for only $4 \%$ of total $\mathrm{PM}_{2.5}$ modeled concentrations in the inner domain D1 and $8 \%$ in the outer domain D2. Compared to the WHO annual guideline of $10 \mu \mathrm{g} \mathrm{m}^{-3}$ and $24 \mathrm{~h}$ average guideline of $25 \mu \mathrm{g} \mathrm{m}^{-3}, \mathrm{PM}_{2.5}$ concentrations exceed these values in large urban agglomerations such as Beirut and Tripoli and in the regions of Chekka and Sibline where several cement plants are located and modeled $\mathrm{PM}_{2.5}$ are above $100 \mu \mathrm{g} \mathrm{m}^{-3}$.

Statistical model performance at the USJ site are presented in Tables 6 and 7. The observed value for $\mathrm{PM}_{2.5}$ is a reconstructed mass concentration based on the IMPROVE method (IMPROVE, 2011; $\mathrm{PM}_{2.5}=1.8 \cdot \mathrm{OC}+\mathrm{EC}+1.375 \cdot$ sulfate $+1.29 \cdot$ nitrate $+1.8 \cdot \mathrm{Cl}+2.2 \cdot \mathrm{Al}+2.49 \cdot \mathrm{Si}+1.63 \cdot \mathrm{Ca}$ $+2.42 \cdot \mathrm{Fe}+1.94 \cdot \mathrm{Ti})$. Overall, the model reproduces satisfactorily $\mathrm{PM}_{2.5}, \mathrm{OC}, \mathrm{EC}$, and sulfate $\left(\mathrm{SO}_{4}^{2-}\right)$ average concentrations. MFB values in the range of -62 to $25 \%$ and MFE values in the range of 39 to $65 \%$ obtained during this study indicate that the model meets the performance criteria $(-60 \% \leq \mathrm{MFB} \leq+60 \%$ and MFE $\leq 75 \%)$ proposed by Boylan and Russel (2006). For nitrate and ammonium, there is a large underestimation of the model. This high underestimation could be related in part to uncertainties in $\mathrm{NH}_{3}$ emissions. On the other hand, the measured nitrate concentrations could be overestimated due to adsorption of nitric acid on the particulate filters because no denuder was placed upstream of the filters. The MFB and MFE reported values of -59 and $-62 \%$ and 61 and $65 \%$ obtained for OC during this study are in agreement with the values of $-37 \%$ and $50 \%$ reported for Europe in another simulation conducted using Polyphemus/Polair3D (Couvidat et al., 2012). In a simulation conducted with the CMAQ model over the eastern US, MFB values for $\mathrm{PM}_{2.5}$, OC and $\mathrm{EC}$ were $-3 \%, 37 \%$ and $14 \%$, respectively (Bailey et al., 2007). Those are lower than the values reported here (Tables 6 and 7). However, for sulfate a MFB of $25-26 \%$ reported here is lower in absolute value than the value of $-35 \%$ reported by Bailey et al. (2007).

\section{Conclusion and future prospects}

A modeling study of meteorology and air pollution in Beirut was conducted for the period of 2-18 July 2011 using WRF and Polyphemus/Polair3D. WRF reproduces satisfactorily 
the diurnal variations for temperature, wind speed, relative humidity and atmospheric pressure and agrees relatively well with observation of wind direction especially from 6 to 10 July 2011. The WRF results show acceptable performance compared to other studies in Europe and the United States; however, measurements were available for model performance evaluation only at one site. The air quality modeling results in Beirut, show higher $\mathrm{NO}_{2}$ concentrations near the coast in the city of Beirut and its northern suburb and lower $\mathrm{O}_{3}$ concentrations within the city limits. Highest values for $\mathrm{PM}_{2.5}$, OC, and EC are modeled within the city limits suggesting that the major sources that lead to the formation of $\mathrm{PM}_{2.5}$ are anthropogenic sources. The CTM performance evaluation results show that Polyphemus/Polair3D reproduces satisfactorily $\mathrm{O}_{3}$ (simulation A4), $\mathrm{PM}_{2.5}$, OC, EC, and sulfate concentrations (both simulations A1 and A4).

Statistical indicators obtained for the major pollutants are in the range of other studies conducted in Europe and US, Furthermore, the $\mathrm{O}_{3}$ diurnal variation is well reproduced by the model, except for secondary morning peaks that are observed on some days but not reproduced by the model. This modeling study is the first one conducted for Beirut. It provides an overview of the pollutant concentrations in the summer of 2011. Future work should focus on the improvement of the input data such as the emission inventory and the meteorology in order to reduce bias and errors between modeled and observed concentrations. Accordingly, specific emission factors for Lebanon, which are inexistent up to now, are needed as future improvements. These emissions factors could be obtained through measurement campaigns at several point sources. In particular, a measurement campaign in a road tunnel in Beirut is highly recommended in order to obtain specific road transport emission factors representative of the Lebanese fleet. Moreover, the development of a regional emission inventory for the Middle East region would help to reduce biases and errors generated from the boundary conditions due to large uncertainties related to emission inventories in this region. Furthermore, observational data from more than one site, typically two or three sites in the city of Beirut, are needed to better evaluate the model. In particular, measurements of meteorological variables at many sites are needed to better reproduce the meteorology through data assimilation and measurements of particulate pollutants and gases are needed to evaluate the model accuracy to reproduce these pollutant concentrations in various areas of the study domain. In addition, measurements of meteorology and pollutant concentrations aloft, including the PBL height are needed in order to evaluate the ability of the meteorological and air quality models to reproduce the complex processes of land-sea breeze, mountain valley winds, and the urban heat island.
Acknowledgements. Funding for this study was provided by École des Ponts ParisTech, the Lebanese National Council for Scientific Research and the Saint Joseph University (Faculty of Sciences and the Council for Research). The authors acknowledge Thierry Leonardis, Servanne Chevaillier and Sylvain Triquet for providing observational data for $\mathrm{CO}, \mathrm{VOC}, \mathrm{NO}_{\mathrm{x}}, \mathrm{O}_{3}$ and major components of fine particulate matter $\left(\mathrm{PM}_{2.5}\right)$.

Edited by: Y. Balkanski

\section{References}

Afif, C., Dutot, A., Jambert, C., Abboud, M., Adjizian-Gérard, J., Farah, W., Perros, P., and Rizk, T.: Statistical approach for the characterization of $\mathrm{NO}_{2}$ concentrations in Beirut, Air Quality, Atmosphere \& Health, 2, 57-67, 2009.

Borge, R., Alexandrov, V., José del Vas, J., Lumbreras, J., and Rodriguez, E.: A comprehensive sensitivity analysis of the WRF model for air quality applications over the Iberian Peninsula, Atmos. Environ., 42, 8560-8574, 2008.

Bailey, E. M., Gautney, L. L., Kelsoe, J. J., Jacobs, M. E., Mao, Q., Condrey, J. W., Pun, B., Yu, S. Y., Seigneur, C., Douglas, S., Heney, J., and Kumar, N.: A comparison of the performance of four air quality models for the Southern oxidants study episode in July 1999, J. Geophys. Res., 112, D05306, doi:10.1029/2005JD007021, 2007.

Boylan, J. W. and Russell, A. G.: PM and light extinction model performance metrics, goals, and criteria for three-dimensional air quality models, Atmos. Environ., 40, 4946-4959, 2006.

Byun, D. and Schere, K. L.: Review of the governing equations, computational algorithms and other components of the models3 community multi scale air quality (CMAQ) modeling system, Applied Mechanics Review, 59, 51, 2006.

Carvalho, D., Rocha, A., Gomez-Gesteira, M., and Santos, C.: A sensitivity study of WRF model in wind simulation for an area of high wind energy, Environ. Modell. Softw., 33, 23-34, 2012.

Cavalli, F., Viana, M., Yttri, K. E., Genberg, J., and Putaud, J.-P.: Toward a standardised thermal-optical protocol for measuring atmospheric organic and elemental carbon: the EUSAAR protocol, Atmos. Meas. Tech., 3, 79-89, doi:10.5194/amt-3-79-2010, 2010.

CBDE, Consensus of buildings and establishments report. Central Administrate of Statistics, Beirut, Lebanon, www.cas.gov.lb, 2004.

Chélala, C.: Transport routier et pollution de l'air en $\mathrm{NO}_{2}, \mathrm{PhD}$ thesis, Université Saint Joseph, Lebanon, 2008.

Chen, W., Kuze, H., Uchiyama, A., Suzuki, Y., and Takeuchi, N.: One-year observation of urban mixed layer characteristics at Tsukuba, Japan using a micro pulse lidar, Atmos. Environ., 35, 4273-4280, 2001.

Chou, M.-D. and Suarez, M. J.: An efficient thermal infrared radiation parameterization for use in general circulation models, NASA Technical Memorandum, 104606, 3:85, 1994.

Couvidat, F., Debry, É., Sartelet, K., and Seigneur, C.: A hydrophilic/hydrophobic organic $\left(\mathrm{H}^{2} \mathrm{O}\right)$ aerosol model: Development, evaluation and sensitivity analysis, J. Geophys. Res., 117, D10304, doi:10.1029/2011JD017214, 2012.

Couvidat, F., Kim, Y., Sartelet, K., Seigneur, C., Marchand, N., and Sciare, J.: Modeling secondary organic aerosol in an urban area: 
application to Paris, France, Atmos. Chem. Phys., 13, 983-996, doi:10.5194/acp-13-983-2013, 2013.

Debry, E., Fahey, K., Sartelet, K., Sportisse, B., and Tombette, M.: Technical Note: A new SIze REsolved Aerosol Model (SIREAM), Atmos. Chem. Phys., 7, 1537-1547, doi:10.5194/acp-7-1537-2007, 2007.

Emmons, L. K., Walters, S., Hess, P. G., Lamarque, J.-F., Pfister, G. G., Fillmore, D., Granier, C., Guenther, A., Kinnison, D., Laepple, T., Orlando, J., Tie, X., Tyndall, G., Wiedinmyer, C., Baughcum, S. L., and Kloster, S.: Description and evaluation of the Model for Ozone and Related chemical Tracers, version 4 (MOZART-4), Geosci. Model Dev., 3, 43-67, doi:10.5194/gmd3-43-2010, 2010.

ESCWA. Transport for sustainable development for the Arab region: Measures, progress achieved, Challenge and policy framework report, http://www.escwa.un.org/information/publications/ edit/.../SDPD-09-w1.pdf, 2010.

Gilliam, R. C., Hogrefe, C., and Rao, S.: New methods for evaluating meteorological models used in air quality applications, Atmos. Environ., 40, 5073-5086, 2006.

Grell, G. A. and Devenyi, D.: A generalized approach to parameterizing convection combining ensemble and data assimilation techniques, Geophys. Res. Lett., 29, 38.1-38.4, 2002.

Grell, G. A., Peckham, S. E., Schmitz, R., McKeen, S. A., Frost, G., Skamarock, W. C., and Eder, B.: Fully coupled online chemistry within the WRF model, Atmos. Environ., 39, 695-6975, 2005.

Guenther, A., Karl, T., Harley, P., Wiedinmyer, C., Palmer, P. I., and Geron, C.: Estimates of global terrestrial isoprene emissions using MEGAN (Model of Emissions of Gases and Aerosols from Nature), Atmos. Chem. Phys., 6, 3181-3210, doi:10.5194/acp-63181-2006, 2006.

Hong, S.-Y., Noh, Y., and Dudhia, J.: A new vertical diffusion package with an explicit treatment of entrainment processes, Mon. Weather Rev., 134, 2318-2341, 2006.

Horowitz, L. W., Fiore, A. M., Milly, G. P., Cohen, R. C., Perring, A., Wooldridge, P. J., Hess, P. G., Emmons, L. K., and Lamarque, J. F.: Observational constraints on the chemistry of isoprene nitrates over the eastern United States, J. Geophys. Res., 112, D12S08, doi:10.1029/2006JD007747, 2007.

IIASA: Average annual anthropogenic heat flux for major capital cities in the world, Retrieved from http//www.iiasa.ac.at/ research/TNT/WEB/heat/, 2012.

IMPROVE: Spatial and seasonal patterns and temporal variability of haze and its constituents in the United States: Report V, June, 2011. Interagency monitering of protected visual environement, chapter 2,Spatial patterns of speciated $\mathrm{PM}_{2.5}$ aerosol mass concentrations, 38 pp., available at: http://vista.cira.colostate.edu/ improve/publications/Reports/2011/PDF/Chapter2.pdf, 2011.

Jiménez-Guerrero, P., Jorba, O., Baldasano, J. M., and Gasso, S.: The use of a modelling system as a tool for air quality management: Annual high-resolution simulations and evaluation, Sci. Total Environ., 390, 323-340, doi:10.1016/j.scitotenv.2007.10.025, 2008.

Kessler, E.: On the distribution and continuity of water substance in atmospheric circulation, Meteorological Monographs, 32, 84 pp., 1969.

Kim, Y:: Modélisation de la qualité de l'air: Évaluation des paramétrisations chimiques et météorologiques, $\mathrm{PhD}$ thesis, 159 pp., 2011.
Kim, Y., Sartelet, K., and Seigneur, C.: Comparison of two gasphase chemical kinetic mechanisms of ozone formation over Europe, J. Atmos. Chem., 62, 89-119, 2009.

Kim, Y., Couvidat, F., Sartelet, K., and Seigneur, C.: Comparison of different gas-phase mechanisms and aerosol modules for simulating particulate matter formation, J. Air Waste Manage. Assoc., 61, 126, 2011.

Kouvarakis, G., Tsigaridis, K., Kanakidou, M., and Mihalopoulos, N.: Temporal variations of surface regional background ozone over Crete Island in the southeast Mediterranean, J. Geophys. Res., 105, 4399-4407, 2000.

Kusaka, H., Kondo, H., Kikegawa, Y., and Kimura, F.: A Simple Single-Layer Urban Canopy Model For Atmospheric Models: Comparison With Multi-Layer And Slab Models, Bound.-Lay. Meteorol., 101, 329-358, 2001.

Lelieveld, J., Berresheim, H., Borrmann, S., Crutzen, P. J., Dentener, F. J., Fischer, H., Feichter, J., Flatau, P. J., Heland, J., Holzinger, R., Korrmann, R., Lawrence, M. G., Levin, Z., Markowicz, K. M., Mihalopoulos, N., Minikin, A., Ramanathan, V., de Reus, M., Roelofs, G. J., Scheeren, H. A., Sciare, J., Schlager, H., Schultz, M., Siegmund, P., Steil, B., Stephanou, E. G., Stier, P., Traub, M., Warneke, C., Williams, J., and Ziereis, H.: Global Air Pollution Crossroads over the Mediterranean, Science, 298, 794-799, 2002.

Lelieveld, J., Hoor, P., Jöckel, P., Pozzer, A., Hadjinicolaou, P., Cammas, J.-P., and Beirle, S.: Severe ozone air pollution in the Persian Gulf region, Atmos. Chem. Phys., 9, 1393-1406, doi:10.5194/acp-9-1393-2009, 2009.

Liu, J., Jones, D., Worden, J., Noone, D., Parrington, M., and Kar, J.: Analysis of the summertime buildup of tropospheric ozone abundances over the Middle East and North Africa 15 as observed by the Tropospheric Emission Spectrometer instrument, J. Geophys. Res., 114, D05304, doi:10.1029/2008JD010993,6345, 2009.

Louis, J.-F.: A parametric model of vertical eddy fluxes in the atmosphere. Bound.-Lay. Meteorol., 17, 187-202, 1979.

Mallet, V., Quélo, D., Sportisse, B., Ahmed de Biasi, M., Debry, É., Korsakissok, I., Wu, L., Roustan, Y., Sartelet, K., Tombette, M., and Foudhil, H.: Technical Note: The air quality modeling system Polyphemus, Atmos. Chem. Phys., 7, 5479-5487, doi:10.5194/acp-7-5479-2007, 2007.

Martilli, A., Clappier, A., and Rotach, M. W.: An Urban Surface Exchange Parameterisation for Mesoscale Models, Bound.-Lay. Meteorol., 104, 261-304, 2002.

Massoud, R., Shihadeh, A., Roumié, M., Youness, M., Gerard, J., Saliba, N., Zaarour, R., Abboud, M., Farah, W., and Saliba, N. A.: Intraurban variability of PM10 and $\mathrm{PM}_{2.5}$ in an Eastern Mediterranean city, Atmos. Res., 101, 893-901, 2011.

Matthias, V., Aulinger, A., and Quante, M.: Adapting CMAQ to investigate air pollution in north Sea coastal region, Environ. Modell. Softw., 23, 356-368, 2008.

Mlawer, E. J., Taubman, S. J., Brown, P. D., Iacono, M. J., and Clough, S. A.: Radiative transfer for inhomogeneous atmospheres : RRTM, a validated correlated-k model for thelongwave, J. Geophys. Res., 102, 16663-16682, 1997.

Mellor, G. L and Yamada, T.: A hierarchy of turbulence closure models for planetary boundary layers, J. Atmos. Sci., 31, 17911806, 1974.

MoE: National environmental action plan. Ministry of environment, Beirut, Lebanon, 2005 
Molders, N.: Suitability of the Weather Research and Forecasting (WRF) Model to Predict the June 2005 Fire Weather for Interior Alaska, Weather Forecast., 23, 953-973, 2008.

Nakanishi, M. and Niino, H.: An Improved Mellor - Yamada Level3 Model with Condensation Physics: Its Design and Verification, Bound.-Lay. Meteorol., 112, 1-31, 2004.

Nenes, A., Pandis, S. N., and Pilinis, C.: ISORROPIA : A new thermodynamic equilibrium model for multiphase multicomponent inorganic aerosols, Aquat. Geochem., 4, 123-152, 1998.

Roeckner, E., Brokopf, R., Esch, M., Giorgetta, M., Hagemann, S., Kornbluh, L., Manzini, L. E., Schlese, U., and Schulzweida, U.: Sensitivity of simulated climate to horizontal and vertical resolution in the ECHAM5 atmosphere model, J. Climate, 19, 37713791, 2006.

Russell, A. and Dennis, R.: NARSTO critical review of photochemical models and modeling, Atmos. Environ., 34, 2283-2324, 2000 .

Salamanca, F., Krpo, A., Martilli, A., and Clappier, A.: A new building energy model coupled with an urban canopy parameterization for urban climate simulations - part I. formulation, verification, and sensitivity analysis of the model, Theor. Appl. Climatol., 99, 331-344, 2010.

Saliba, N. A., Moussa, S., Salame, H., and El-Fadel, M.: Variation of selected air quality indicators over the city of Beirut, Lebanon: Assessment of emission sources, Atmos. Environ., 40, 32633268, 2006.

Saliba, N. A., Kouyoumdjian, H., and Roumié, M.: Effect of local and long-range transport emissions on the elemental composition of $\mathrm{PM}_{10-2.5}$ and $\mathrm{PM}_{2.5}$ in Beirut, Atmos. Environ., 41, 64976509, 2007.

Sartelet, K. N., Debry, E., Fahey, K., Roustan, Y., Tombette, M., and Sportisse, B.: Simulation of aerosols and gas-phase species over Europe with the Polyphemus system: Part I: Model-to-data comparison for 2001, Atmos. Environ., 41, 6116-6131, 2007.

Sartelet, K. N., Hayami, H., and Sportisse, B.: MICS Asia Phase II: "Sensitivity to the aerosol module, Atmos. Environ., 42, 35623570, 2008.

Sartelet, K. N., Couvidat, F., Seigneur, C., and Roustan, Y.: Impact of biogenic emissions on air quality over Europe and North America, Atmos. Environ., 53, 131- 141, 2012.
Skamarock, W. C., Klemp, J. B., Dudhia, J., Gill, D. O., Barker, D. M., Duda, M. G., Wang, X.-Y. H. W., and Powers, J. G.: A description of the Advanced Research WRF version 3. NCAR Technical note, $-475+$ STR, 2008.

Smoydzin, L., Fnais, M., and Lelieveld, J.: Ozone pollution over the Arabian Gulf - role of meteorological conditions, Atmos. Chem. Phys. Discuss., 12, 6331-6361, doi:10.5194/acpd-126331-2012, 2012.

Stavrakou, T., Müller, J. F., Boersma, K. F., De Smedt, I., and van der A, R. J.: Assessing the distribution and growth rates of $\mathrm{NO}_{\mathrm{x}}$ emission sources by inverting a 10 -year record of $\mathrm{NO}_{2}$ satellite columns, Geophys. Res. Lett., 35, L10801, doi:10.1029/2008GL033521, 2008.

Stull, R. B.: An introduction to boundary layer meteorology, Kluwer Academic Publishers, Dordrecht, 1988.

Troen, I. B. and Mahrt, L.: A simple model of the atmospheric boundary layer, sensitivity to surface evaporation, Bound.-Lay. Meteorol., 37, 129-148, 1986.

Waked, A.: Caractérisation des aerosols organiques à Beyrouth, Liban, PhD thesis, 173 pp., 2012.

Waked, A. and Afif, C. Emissions of air pollutants from road transport in Lebanon and other countries in the Middle East region, Atmos. Environ., 61, 446-452, 2012.

Waked, A., Afif, C., and Seigneur, C.: An atmospheric emission inventory of anthropogenic and biogenic sources for Lebanon, Atmos. Environ., 50, 88-96, 2012.

Yarwood, G., Rao, S., Yocke, M., and Whitten, G.: Updates to the carbon bond chemical mechanism: CB05 final report to the US EPA, RT-0400675, 2005.

Yu, S., Eder, B., Dennis, R., Chu, S.-H., and Schwartz, S. E.: New unbiased symmetric metrics for evaluation of air quality models, Atmos. Sci. Lett., 7, 26-34, 2006.

Zhang, Y., Liu, P., Pun, B., and Seigneur, C.: A comprehensive performance evaluation of MM5-CMAQ for the summer 1999 Southern Oxidants Study episode Part I: Evaluation protocols, databases, and meteorological predictions, Atmos. Environ., 40, 4825-4838, 2006.

Zhang, Y., Dubey, M. K., Olsen, S. C., Zheng, J., and Zhang, R.: Comparisons of WRF/Chem simulations in Mexico City with ground-based RAMA measurements during the 2006-MILAGRO, Atmos. Chem. Phys., 9, 3777-3798, doi:10.5194/acp-9-3777-2009, 2009. 